\title{
Determination of the Difficult Intubation Incidence and its Affecting Factors in Patients Undergoing Septal Deviation Surgery - Prospective Controlled Trial
}

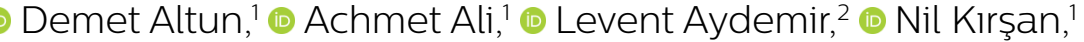 \\ (1) Mukadder Orhan Sungur,' ${ }^{1}$ Emre Çamcl ${ }^{1}$
}

\begin{abstract}
'Department of Anesthesiology, İstanbul University Istanbul Faculty of Medicine, İstanbul, Turkey

${ }^{2}$ Department of Otolaryngology,

Head and Neck Surgery, İstanbu University Istanbul Faculty of Medicine, İstanbul, Turkey

Submitted: 10.04 .2019 Accepted: 26.08.2019

Correspondence: Demet Altun İstanbul Üniversitesi İstanbul Tıp Fakültesi, Anesteziyoloj Anabilim Dalı, İstanbul, Turkey

E-mail: drdemetaltun@hotmail.com
\end{abstract}

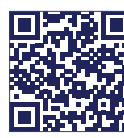

Keywords: CormackLehane classification; difficult airway; Mallampati test; micrognathia; septal deviation; sleep apnea syndrome.

This work is licensed under a Creative Commons Attribution-NonCommercial 4.0 International License.

\begin{abstract}
Objective: The aim of this prospective clinical study was to compare the incidence of difficult airway in patients undergoing septal deviation with the incidence of difficult airway in patients undergoing tympanoplasty and to determine the factors associated with the incidence of the difficult airway. Investigation of predisposing factors for difficult airway in patients undergoing septal deviation surgery was evaluated as a secondary outcome.
\end{abstract}

Methods: A total of 255 participants, 130 patients undergoing septoplasty (study groupGroup S) and 125 patients undergoing tympanoplasty (control group-Group T) were included in this study. Preoperative airway evaluation was performed using the LEMON protocol. For all patients, the STOP-BANG questionnaire was performed to identify the risk of Obstructive Sleep Apnea Syndrome (OSAS). Cormack-Lehane laryngeal view grades were noted during laryngoscopy. The definition of difficult intubation was identified according to the Cormack-Lehane scale ( $I-I I=$ easy, III-IV=difficult). Additionally, the intubation method used, number of intubation attempts, use of stylet, cricoid pressure, and usage of airway were recorded.

Results: There were no unintubated patients in this study population. Cormack-Lehane score and incidence of difficult airway were significantly higher in the Group $S$ than the Group T $(p<0.001)$. Micrognathia ( $<<0.001$, OR: $9.38,95 \% \mathrm{Cl}: 2.71-45.93)$ and OSAS ( $p<0.00$ I, OR: $58.013,95 \% \mathrm{Cl}$ : 14.025-239.98) were found to be risk factors for difficult airway in patients undergoing septoplasty.

Conclusion: The airway should be evaluated for difficult intubation before surgery and risk factors for difficult airway should be determined even in minor surgery.

\section{INTRODUCTION}

Deviated septum is one of the most common types of nasal obstruction. ${ }^{[1]}$ The irregular form of the nasal septum may partially block the airflow and impede breathing. ${ }^{[2,3]}$ On the other hand, several studies suggest a possible link between nasal obstruction and OSAS. ${ }^{4-6]}$ A patient with nasal obstruction will often have an open mouth during sleep, and this response contributes to sleep-associated breathing disorders, including snoring and sleep apnea, by narrowing the pharyngeal lumen.

The action of opening the mouth during sleep causes the chin and the mandible to move posteroinferiorly along with the tongue. ${ }^{[7,8]}$ This consequently restricts the pharyngeal air passage.

Septoplasty is the required surgery for patients with snoring and mild to moderate OSAS that at the same time have blocked nasal passage due to a deviated nasal septum.

Surgical treatment of deviated septum (septoplasty) can ease the passage of air and decrease the resistance in the upper airway, and thus resulting in a reduction in the severity of snoring and OSAS. ${ }^{[9,10]}$ Another important point demonstrated by several studies was the strong association between nasal septum deviation and asymmetric facial growth, such as maxillary and mandibular abnormality. ${ }^{[1-13]}$ 
Although septoplasty is a minor operation with low anesthesia risk, accompanying OSAS and facial asymmetry are often associated with an increased risk of difficult intubation. Patients undergoing septoplasty surgery are preoperatively evaluated by medical history, physical examination, and tests; however, the risk of difficult intubation cannot always be foreseen. We should note that preoperative evaluation tests for the prediction of difficult intubation is helpful and necessary for arranging the required preincubation preparation when potentially difficult intubation is predicted. However, to our knowledge, there are not any data regarding the incidence of difficult intubation and factors associated with the incidence of difficult airway in deviated septum patients who request septoplasty surgery. Thus, in this prospective clinical study, we aimed to assess the incidence of difficult airway in patients who may have abnormal airway evaluation parameters undergoing septal deviation surgery. Factors associated with the incidence of difficult airway undergoing septal deviation surgery were evaluated as secondary outcomes.

\section{MATERIALS AND METHODS}

This prospective study was approved by Istanbul University, Istanbul Faculty of Medicine Ethics Committee (2018/744) and written informed consent was obtained from each patient. American Society of Anesthesiologists (ASA) I and II patients (18-65 years old), whose main complaint was nasal stuffiness due to nasal septum deviation that poses an indication for septoplasty requiring tracheal intubation were included to this study.

The control group was formed from patients undergoing tympanoplasty surgery without a complaint of nasal obstruction in the Department of Ear Nose Throat.

A total of 255 participants, including 130 patients undergoing septoplasty and 125 patients undergoing tympanoplasty, were included in this study.

Patients with a history of difficult intubation and facial trauma or congenital craniofacial deformities, and difficult mask ventilation during the procedure were excluded from this study.

Before the airway evaluation, pre-anesthetic medication was not administered. Preoperative airway evaluation was performed in all patients using the following LEMON protocol. ${ }^{[14-16]}$ before general anesthesia; for the 'look' criteria we assessed micrognathia, mouth opening distance (MOD, interincisor distance, $\mathrm{cm}$ ), presence of abnormal protruding upper teeth, macroglossia; for the 'evaluate' criteria thyromental distance (TMD, the distance from the mentum to the thyroid notch, $\mathrm{cm}$ ), sternomental distance (SMD, the distance from the suprasternal notch to the mentum, cm); for 'Mallampati' criteria modified Mallampati classification (I-2-3-4);[17] for 'obstructed' airway presence of OSAS; for the 'neck' criteria neck circumference (at the level of the thyroid cartilage).

For all patients, STOP-BANG questionnaire ${ }^{[18]}$ was performed to identify the risk of OSAS. The STOP-BANG questionnaire test consists of eight yes or no questions. ${ }^{[19]}$ STOP-BANG stands for $\mathbf{S}$ - history of snoring, $\mathbf{T}$ - history of tiredness, $\mathbf{O}$ - observed apnea during sleep, $\mathbf{P}$ - blood pressure (hypertension), $\mathbf{B}$ - body mass index (BMI) $>35$ $\mathrm{kg} / \mathrm{m}^{2}, \mathbf{A}$ - age $>50$ years, $\mathbf{N}$ - neck circumference $>40$ $\mathrm{cm}, \mathbf{G}-$ male gender. Each positive response was given a point and patients with a score of $>3$ in the STOP-BANG test were accepted as patients having OSAS and those $<3$ not having OSAS.

Standard monitoring was applied, consisting of electrocardiography (ECG), noninvasive blood pressure, peripheral oxygen saturation $\left(\mathrm{SpO}_{2}\right)$.

Standard anesthetic technique, including midazolam $0.05 \mathrm{mg}$ $\mathrm{kg}^{-1}$, propofol 2-3 $\mathrm{mg} \mathrm{kg}^{-1}$, fentanyl $1.5 \mathrm{\mu g} \mathrm{kg}^{-1}$ and rocuronium $0.6 \mathrm{mg} \mathrm{kg}^{-1}$, were applied to all the patients. After anesthesia, induction patients were ventilated with $100 \%$ oxygen using a face mask. If required, oropharyngeal airway was inserted. We monitored the train-of-four (TOF) ratio, and intubation was performed at 0/4. A 3 No and 4 No Macintosh blades were used for female and male patients, respectively. All intubation procedures were performed by an anesthesiologist specialized in the ENT department. Cormack-Lehane laryngeal view grades were noted during laryngoscopy. The determination of difficult intubation was identified according to the Cormack-Lehane scale.

Intubation was accepted easy for grade I or II, and difficult for grade III or IV. If the resident was not able to intubate in three attempts with Macintosh laryngoscope next step was performing the intubation with the C-Mac videolaryngoscope and the third step was Laryngeal Mask Airway (LMA) insertion. Correct positioning of the tube in the trachea was verified after intubation, preferably by visual confirmation of the tube passing through the glottic aperture, auscultation of the chest by a stethoscope and normal capnograph traces. If the LMA trial was unsuccessful, the last step was ventilation using facemask and allowing the patient to wake up considering reversal with sugammadex (4-5 mg/kg).

Intubation stylet was used if required in case of intubation failure at first attempt. During intubation attempts, the patient was ventilated with $100 \%$ oxygen using face mask. The intubation method used, the total number of attempts for successful intubation, use of a stylet, application of optimal external laryngeal manipulation (cricoid pressure), and oropharyngeal airway insertion during facemask ventilation were recorded.

\section{Statistical analysis}

The statistical analyses were performed using NCSS (Number Cruncher Statistical System) 2007 (Kaysville, Utah, USA). The data were presented as mean $\pm S D$ (standard deviation), median [minimum-maximum], or the number of patients (\% of total). Mann-Whitney $U$ test and Student's t-test were used to compare the quantitative variables. Normal distribution was assessed using the Shapiro-Wilk test. Binary data were compared with the Pearson Chisquared test, Fisher's exact test or Fisher- Freeman-Halton 
exact test. $P<0.05$ was considered to be statistically significant. Binary logistic regression was performed to identify the predictors of difficult airway for micrognathia, thyromental distance, sternomental distance, Mallampati classification, macroglossia, neck circumference, presence of OSAS. The odds ratio (OR) and $95 \%$ confidence intervals (Cl) were stated for independent risk factors detected.

After performing a pilot study of 30 patients undergoing septoplasty surgery, $10 \%$ incidence of difficult intubation was observed during laryngoscopy. Based on this result, we assumed that 108 patients would be required in each group when predicting that the incidence was at least $10 \%$ with patients undergoing septoplasty (assuming $\alpha=0.05$ and $\beta=0.2$ ). Therefore, we a priori decided to include at least 120 patients considering the dropouts.

\section{RESULTS}

During the three months study period, a total of 270 patients requiring general anesthesia with endotracheal intubation in the ENT department were screened. Eight patients refused to participate in this study, and 262 consenting patients were enrolled. During the anesthetic induction period, seven patients were excluded from this study due to the history of difficult intubation and difficult mask ventilation during the procedure.

Data from the remaining 255 patients were included in the statistical analysis (Fig. I).

Among 255 cases, 130 (51\%) underwent septoplasty (Group S) and 125 (49\%) underwent tympanoplasty (Group T) surgery.

The characteristics of the patients and the incidence of difficult intubation and Cormack-Lehane scores between the groups are presented in Table $I$.
There were no significant differences between the groups concerning age, gender, height, weight and ASA physical status. No impossible intubations were encountered. In comparison between groups, Cormack-Lehane score was significantly higher in Group $S$ than in Group $T(p<0.001)$ and the incidence of difficult intubation was higher in Group $S$ than in Group T [n=65 (50\%), n=12 (9.6\%), respectively, $\mathrm{p}<0.00 \mathrm{I}$ ] (Table I).

The univariate analysis for the factors associated with difficult intubation "micrognathia, presence of abnormal protruding teeth, mouth opening, thyromental distance, sternomental

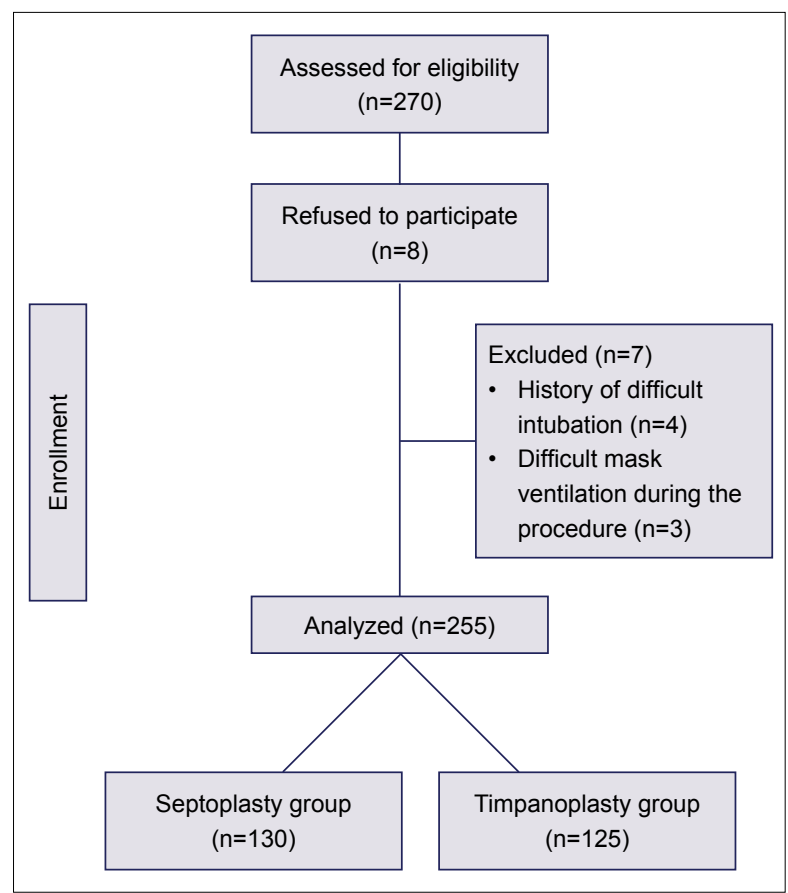

Figure 1. The flow diagram of this study.

Table I. The characteristics of the patients and the incidence of difficult intubation and Cormach-Lehane scores among the groups

\begin{tabular}{|c|c|c|c|c|c|c|c|}
\hline & \multicolumn{3}{|c|}{ Group S } & \multicolumn{3}{|c|}{ Group T } & \multirow[t]{2}{*}{$\mathbf{p}$} \\
\hline & $\mathbf{n}$ & $\%$ & Mean $\pm S D$ & $\mathbf{n}$ & $\%$ & Mean $\pm S D$ & \\
\hline \multicolumn{8}{|l|}{ Gender } \\
\hline Male & 87 & 66.9 & & 60 & 48 & & 0.002 \\
\hline Female & 43 & 33.1 & & 65 & 52 & & \\
\hline Age (years) & & & $34.01 \pm 9.66$ & & & $35.66 \pm 8.79$ & 0.154 \\
\hline Height $(\mathrm{cm})$ & & & $171.73 \pm 8.89$ & & & $169.74 \pm 7.62$ & 0.056 \\
\hline Weight (kg) & & & $75.88 \pm 13.84$ & & & $72.79 \pm 12.89$ & 0.067 \\
\hline \multicolumn{8}{|c|}{ Cormach-Lehane score $(1 / 2 / 3 / 4)$} \\
\hline 1 & 10 & 7.7 & & 95 & 76 & & $<0.001$ \\
\hline 2 & 55 & 42.3 & & 18 & 14.4 & & $<0.001$ \\
\hline 3 & 65 & 50 & & 12 & 9.6 & & $<0.001$ \\
\hline \multicolumn{8}{|c|}{ Difficult Intubation } \\
\hline Yes & 65 & 50 & & 113 & 90.4 & & $<0.001$ \\
\hline No & 65 & 50 & & 12 & 9.6 & & \\
\hline
\end{tabular}


distance, Mallampati classification, macroglossia, neck circumference, presence of OSAS and snoring" between the groups are shown in Table 2. Among these, micrognathia, presence of abnormal protruding upper teeth, mouth opening, thyromental distance, Mallampati classification, macroglossia, neck circumference, presence of OSAS and snoring were found to be statistically significant $(p<0.00 \mathrm{I})$.

Binary logistic regression was later performed for the fol- lowing factors: micrognathia, thyromental distance, sternomental distance, Mallampati classification, macroglossia, neck circumference, presence of OSAS. Among these, micrognathia ( $\mathrm{p}<0.00 \mathrm{I}$, OR: 9.38, 95\% Cl: 2.7I-45.93) and the presence of OSAS ( $p<0.001$, OR: $58.013,95 \% \mathrm{Cl}$ : 14.025-239.98) were found to be independent risk factors for difficult intubation in patients undergone septoplasty surgery (Table 3).

Table 2. The univariate analysis for the factors associated with difficult intubation among the groups

\begin{tabular}{|c|c|c|c|c|c|}
\hline & \multicolumn{2}{|c|}{ Group S } & \multicolumn{2}{|c|}{ Group T } & \multirow[t]{2}{*}{$\mathbf{p}$} \\
\hline & $\mathbf{n}$ & $\%$ & $\mathbf{n}$ & $\%$ & \\
\hline \multicolumn{6}{|l|}{ Micrognathia } \\
\hline Yes & 19 & 14.6 & 116 & 92.8 & $<0.001$ \\
\hline No & III & 85.4 & 9 & 7.2 & \\
\hline \multicolumn{6}{|c|}{ Presence of abnormal protruding upper teeth } \\
\hline Yes & 81 & 62.3 & 125 & 100 & $<0.001$ \\
\hline No & 49 & 37.7 & 0 & 0 & \\
\hline Mouth opening $(\mathrm{cm})$ & 7 & 7.7 & 7 & 7.8 & $<0.001$ \\
\hline Thyromental distance $(\mathrm{cm})$ & 5 & 5.8 & 7 & 7.8 & $<0.001$ \\
\hline Sternomental distance $(\mathrm{cm})$ & 12 & 11.14 & 13 & 13.13 & 0.089 \\
\hline \multicolumn{6}{|c|}{ Mallampati classification $(1 / 2 / 3 / 4)$} \\
\hline 1 & 24 & 18.5 & 49 & 39.2 & $<0.001$ \\
\hline 2 & 78 & 60 & 64 & 51.2 & \\
\hline 3 & 28 & 21.5 & 12 & 9.6 & \\
\hline \multicolumn{6}{|l|}{ Macroglossia } \\
\hline No & 63 & 48.5 & 104 & 83.2 & $<0.001$ \\
\hline Yes & 67 & 51.5 & 21 & 16.8 & \\
\hline Neck circumference $(\mathrm{cm})$ & 39.5 & 37.41 & 37 & 35.38 & $<0.001$ \\
\hline \multicolumn{6}{|l|}{ OSAS } \\
\hline No & 67 & 51.5 & 113 & 90.4 & $<0.001$ \\
\hline Yes & 63 & 48.5 & 12 & 9.6 & \\
\hline \multicolumn{6}{|l|}{ Snoring } \\
\hline No & 47 & 36.2 & 124 & 99.2 & $<0.001$ \\
\hline Yes & 83 & 63.8 & I & 0.8 & \\
\hline
\end{tabular}

OSAS: Obstructive sleep apnea sendyrome; S: Septoplasty; T: Timpanoplasty; SD: Standard deviation.

Table 3. Analysis of the independent risk factors for patients underwent septoplasty surgery

\begin{tabular}{|c|c|c|c|}
\hline & Beta coefficent & $\mathbf{P}$ & OR $(95 \% \mathrm{CI})$ \\
\hline Micrognathia & 9.721 & $<0.001$ & $9.38(2.7 I-45.93)$ \\
\hline Tiromental distance $(\mathrm{cm})$ & 1.463 & 0.226 & $0.355(0.066-1.903)$ \\
\hline Sternomental distance $(\mathrm{cm})$ & 0.531 & 0.466 & $\mathrm{I} .787(0.375-8.5 \mathrm{II})$ \\
\hline \multicolumn{4}{|c|}{ Mallampati classification $(1 / 2 / 3 / 4)$} \\
\hline 1 & 1.670 & 0.434 & \\
\hline 2 & 0.600 & 0.439 & $2.940(0.192-45.078)$ \\
\hline 3 & 1.669 & 0.196 & I I.I $76(0.287-435.286)$ \\
\hline Macroglossia & 2.801 & 0.094 & 7.951 (0.70I-90.149) \\
\hline Neck circumferance $(\mathrm{cm})$ & 3.768 & 0.052 & $1.430(0.997-2.052)$ \\
\hline Presence of OSAS & 31.419 & $<0.001$ & $58.013(14.025-239.976)$ \\
\hline
\end{tabular}


The intubation method used, the total number of attempts for successful intubation are given in Table 4. The percentage of use of a stylet, cricoid pressure, oropharyngeal airway insertion during facemask ventilation between the groups were shown in Figure 2.

Table 4. Details of the intubation method used, number of intubation attempts, total number of attempts for successful intubation

\begin{tabular}{|c|c|c|}
\hline & Number (n) & Prevelance (\%) \\
\hline Classic laryngoscope & 255 & 100 \\
\hline $\begin{array}{l}\text { Number of success in } \\
\left.\right|^{\text {st }} \text { attempt }\end{array}$ & 109 & 42.7 \\
\hline $\begin{array}{l}\text { Number of success in } \\
2^{\text {nd }} \text { attempt }\end{array}$ & 54 & 21.2 \\
\hline $\begin{array}{l}\text { Number of success in } \\
3^{\text {rd }} \text { attempt }\end{array}$ & 29 & 11.4 \\
\hline Number of failure & 63 & 24.7 \\
\hline C-Mac videolaryngoscope & 63 & 24.7 \\
\hline $\begin{array}{l}\text { Number of success in } \\
\left.\right|^{\text {st }} \text { attempt }\end{array}$ & 19 & 30.2 \\
\hline $\begin{array}{l}\text { Number of success in } \\
2^{\text {nd }} \text { attempt }\end{array}$ & 44 & 69.8 \\
\hline $\begin{array}{l}\text { Total number of intubation } \\
\text { attempts }\end{array}$ & & \\
\hline$\left.\right|^{\text {st }}$ trial & 109 & 42.7 \\
\hline $2^{\text {nd }}$ trial & 54 & 21.2 \\
\hline $3^{\text {rd }}$ trial & 39 & 11.4 \\
\hline $4^{\text {th }}$ trial & 21 & 8.2 \\
\hline $5^{\text {th }}$ trial & 42 & 16.5 \\
\hline $\begin{array}{l}\text { Total number of intubation } \\
\text { attempts }\end{array}$ & $1-5$ & $2.34 \pm 1.50$ \\
\hline
\end{tabular}

Data are presented as mean \pm standard deviation $(S D)$ or number of the patients.

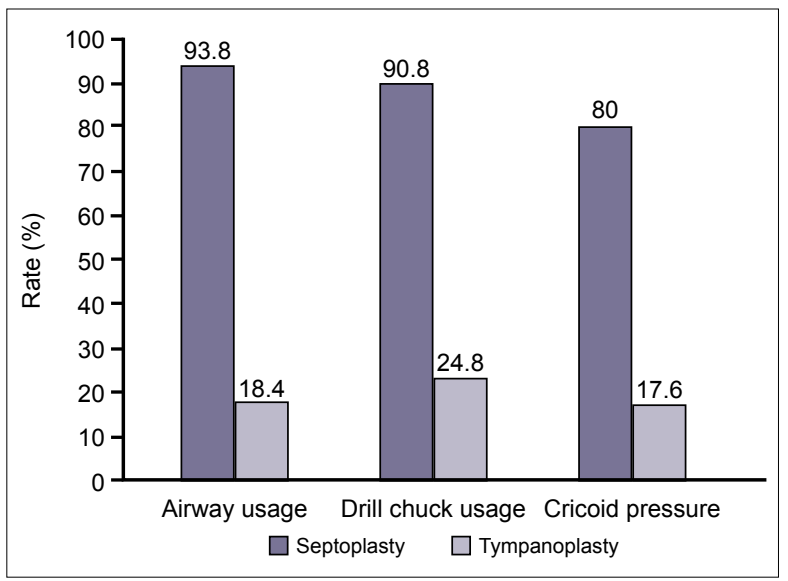

Figure 2. The percentage of use of the stylet, a cricoid pressure, oropharyngeal airway insertion during facemask ventilation between the groups.

\section{DISCUSSION}

This study evaluated the incidence and independent risk factors associated with difficult airway in patients who had undergone septal deviation surgery for a deviated nose. While the difficult intubation incidence has been reported as $1.5-13 \%{ }^{[19]}$ in the literature, the incidence of difficult intubation was found $51 \%$ in patients who underwent septoplasty surgery compared to the patients who underwent tympanoplasty surgery in our study. The difficult intubation is associated with repeated attempts, which are also linked to an increased risk of complications, such as airway trauma, hypoxemia and cardiac arrest. ${ }^{[2,21]}$ On the other hand, most etiological factors for difficult intubation can be detected with elaborated pre-anesthetic evaluation, and precautions to prevent difficult intubation can be taken according to ASA guidelines. The combined assessment of multiple predictors successfully diagnosed difficulty for intubation in preoperative patients. However, the benefit of these combinations has not been demonstrated in septal deviated patients. Given that, it is necessary to emphasize the association of predictive risk factors with difficult airway in the evaluation of septal deviated patients, underlining their complementarity to minimize the negative consequences of repeated laryngoscopies.

Our findings suggest that seven independent predictors (micrognathia, thyromental distance, sternomental distance, macroglossia, neck cicumference, Mallampati classification, presence of OSAS) can help identify patients with and without difficult intubation who undergo septoplasty surgery requiring tracheal intubation. These simple predictors can be assessed easily by anesthesiology residents before initiating intubation. Of these, according to our results, difficult intubation was associated with micrognathia and the presence of OSAS.

When we look at the previous studies, to understand what the breathing problems with deviated septum are, it is stated that patent nasal passage is critical to good breathing, because anything that causes a blockage or narrowing in the upper airway may lead to breathing problems. A patient with nasal obstruction will often have an open mouth during sleep, and this response contributes to sleep-associated breathing disorders, including snoring and sleep apnea. ${ }^{[6,7]}$ OSAS is often associated with increased risk of difficult intubation. ${ }^{[2]}$ Previous studies have shown a wide variation in the prevalence of OSAS, which, in general, is high. ${ }^{[23,24]}$ Our findings showed that in multivariate analysis, the presence of OSAS reached statistical significance in the assessment of difficult airway, which emphasizes the importance of taking a detailed history and examining the patient for OSAS during pre-anesthetic check-up in predicting difficult airway.

Another point was that, while the patient with a deviated septum opens his mouth during sleep, the chin and rest of the mandible move postero-inferiorly along with the tongue, which leads to retrognathia/micrognathia. ${ }^{[12]}$ This directly narrows the pharyngeal airway. 
Previous studies reported that retrognathia/micrognathia was identified as a risk factor for difficult intubation. ${ }^{[25]}$ According to our study, micrognathia ( $p<0.001$, OR: 9.38 , 95\% Cl: $2.7 \mathrm{I}-45.93)$ was found to be an independent risk factor for difficult intubation in patients who underwent septoplasty surgery.

The limitation of our study is that OSAS was diagnosed only clinically using the STOP-BANG questionnaire test, polysomnography was not carried out to confirm the diagnosis of OSAS. Further studies, which include polysomnographic confirmation of OSAS, should be planned.

\section{CONCLUSION}

Anesthesiologists should be aware that micrognathia and the presence of OSAS are associated with difficult airway although the surgery is as simple as septoplasty and these predictors may be useful in the routine test for preoperative prediction of difficult intubation in patients undergoing septoplasty surgery.

Ethics Committee Approval

Approved by Istanbul University, Istanbul Faculty of Medicine Ethics Committee (2018/744).

Peer-review

Internally peer-reviewed.

Authorship Contributions

Concept: D.A., E.Ç.; Design: D.A., M.O.S., E.Ç.; Supervision: A.A.; Fundings: D.A., L.A.; Materials: D.A., N.K., L.A.; Data: D.A.; Analysis: D.A., M.O.S., E.Ç.; Literature Search: D.A., L.A.; Writing: D.A., E.Ç., M.O.S.; Critical Analysis: D.A., E.Ç., A.A.

Conflict of Interest

None declared.

\section{REFERENCES}

1. Özkıııs M, Mutlu C. The incidence of nasal septal deviation in patients admitted to our ENT clinic. J Kartal TR 2010;21:72-6.

2. Linder-Aronson S. Adenoids: their effect on mode of breathing and nasal airflow and their relationship to characteristics of the facial skeleton and the dentition: a biometric, rhino-manometric and cephalometro-radiographic study on children with and without adenoids. Acta Otolaryngol Suppl 1970;265:1-132.

3. Principato JJ. Upper airway obstruction and craniofacial morphology. Otolaryngol Head Neck Surg 1991;104:881-90. [CrossRef]

4. Liistro G, Rombaux P, Belge C, Dury M, Aubert G, Rodenstein DO. High Mallampati score and nasal obstruction are associated risks factors for obstructive sleep apnea. Eur Respir J 2003;21:248-52. [CrossRef]

5. Lofaso F, Coste A, d'Ortho MP, Zerah-Lancner F, Delclaux C, Goldenberg F, et al. Nasal obstruction as a risk factor for obstructive sleep apneoa syndrome. Eur Respir J 2000;16:639-43. [CrossRef]

6. Yang WH, Drouin MA, Herbert M, Mao Y, Karsh J. Nasal obstructions as a risk factor for sleep-disordered breathing. The University of Winsconsin Sleep and Respiratory Research Group. J Allergy Clin Immunol 1997;99:757-62. [CrossRef]
7. Josell SD. Habits affecting dental and maxillofacial growth and development. Dent Clin North Am 1995;39:851-60.

8. Valera FC, Travitzki LV, Mattar SE, Matsumoto MA, Elias AM, Anselmo-Lima WT. Muscular, functional and orthodontic changes in preschool children with enlarged adenoids and tonsils. Int J Pediatr Otorhinolaryngol 2003;67:761-70. [CrossRef]

9. Singh A, Patel N, Kenyon G, Donaldson G. Is there objective evidence that septal surgery improves nasal airflow? J Laryngol Otol 2006;120:916-20. [CrossRef]

10. Virkkula P, Bachour A, Hytönen M, Salmi T, Malmberg H, Hurmerinta K, et al. Snoring Is Not Relieved by Nasal Surgery Despite Improvement in Nasal Resistance. Chest. 2006;129:81-7. [CrossRef]

11. Pirsig W. Growth of the deviated septum and its influence on midfacial development. Facial Plast Surg 1992;8:224-32. [CrossRef]

12. Hafezi F, Naghibzadeh B, Nouhi A, Yavari P. Asymmetric facial growth and deviated nose: a new concept. Ann Plast Surg 2010;64:47-51. [CrossRef]

13. Kim YM, Rha KS, Weissman JD, Hwang PH, Most SP. Correlation of asymmetric facial growth with deviated nasal septum. Laryngoscope 2011;121:1144-8. [CrossRef]

14. Reed MJ, Dunn MJ, McKeown DW. Can an airway assessment score predict difficulty at intubation in the emergency department? Emerg Med J 2005;22:99-102. [CrossRef]

15. Sagarin MJ, Barton ED, Chng YM, Walls RM; National Emergency Airway Registry Investigators. Airway management by US and Canadian emergency medicine residents: a multicenter analysis of more than 6,000 endotracheal intubation attempts. Ann Emerg Med 2005;46:328-36. [CrossRef]

16. Calder I. Identification of the Difficult Airway. Anaesthesia 2011;12:340-2. [CrossRef]

17. Mallampati SR. Clinical assessment of airway. Anesthesiol Clin north Am 1995;13:301-7.

18. Chung F, Yegneswaran B, Liao P, Chung SA, Vairavanathan S, Islam $\mathrm{S}$, et al. STOP questionnaire: a tool to screen patients for obstructive sleep apnea. Anesthesiology 2008;108:812-21. [CrossRef]

19. Cattano D, Panicucci E, Paolicchi A, Forfori F, Giunta F, Hagberg C. Risk Factors Assessment of the Difficult Airway: An Italian Survey of 1956 Patients. Anesth Analg 2004;99:1774-9. [CrossRef]

20. Duchynski R, Brauer K, Hutton K, Jones S, Rosen P. The quick look airway classification. A useful tool in predicting the difficult out-ofhospital intubation: experience in an air medical transport program. Air Med J 1998;17:46-50. [CrossRef]

21. Hasegawa K, Shigemitsu K, Hagiwara Y, Chiba T, Watase H, Brown CA 3rd, et al. Association between repeated intubation attempts and adverse events in emergency departments: an analysis of a multicenter prospective observational study. Ann Emerg Med 2012;60:749-54.e2.

22. Hiremath AS, Hillman DR, James AL, Noffsinger WJ, Platt PR, Singer SL. Relationship between difficult tracheal intubation and obstructive sleep apnoea. Br J Anaesth 1998;80:606-11. [CrossRef]

23. Kapur VK, Auckley DH, Chowdhuri S, Kuhlmann DC, Mehra R, Ramar K, et al. Clinical Practice Guideline for Diagnostic Testing for Adult Obstructive Sleep Apnea: An American Academy of Sleep Medicine Clinical Practice Guideline. J Clin Sleep Med 2017;13:479-504. [CrossRef]

24. Turhan M, Bostancı A, Akdag M, Dinc O. A comparison of the effects of packing or transseptal suture on polysomnographic parameters inseptoplasty. Eur Arch Otorhinolaryngol 2013;270:1339-44.

25. Shah PN, Sundaram V. Incidence and predictors of difficult mask ventilation and intubation. J Anaesthesiol Clin Pharmacol 2012;28:451-5. [CrossRef] 


\section{Septal Deviasyon Ameliyatı Geçirecek Hastalarda Zor Entübasyon İnsidansının ve Etki} Eden Faktörlerin Belirlenmesi: Prospektif Kontrollü Çalışma

Amaç: Bu prospektif klinik çalışmanın amacı septal deviasyon ameliyatı geçirecek hastalardaki zor havayolu insidansını timpanoplasti operasyonu geçirecek hastalardaki zor havayolu insidansı ile karşılaştırmak ve zor havayolu insidansına etki eden faktörlerin belirlenmesidir. Septal deviasyon ameliyatı geçirecek hastalardaki zor havayolu için predispozisyon yaratan faktörlerin araştırılması ikincil çıktı olarak değerlendirilmiştir.

Gereç ve Yöntem: Çalışmaya septoplasti (çalışma grubu-Grup S) uygulanan 130 hasta ve timpanoplasti (kontrol grubu-Grup T) uygulanan 125 hasta olmak üzere toplam 255 katılımcı dahil edildi. Operasyon öncesi havayolu değerlendirilmesi LEMON protokolü kullanılarak yapıldı. Bütün hastalara uyku apne sendromu (UAS) risk tanısı için STOP-BANG soru testi uygulandı. Laringoskopi sırasında Cormack-Lehane laringeal görüntü dereceleri not edildi. Cormack-Lehane skalasına göre zor havayolu tanımlaması yapıldı (I-II=kolay, III-IV=zor). Ek olarak kullanılan entübasyon yöntemi, entübasyon deneme sayısı, stile kullanımı, krikoid bası ve airway kullanımı kaydedildi.

Bulgular: Bu çalışma popülasyonunda entübe edilemeyen hasta olmadı. Cormack-Lehane skoru ve zor havayolu insidansı Grup S'de Grup T'ye göre anlamlı olarak daha yüksek bulundu ( $p<0.001$ ). Mikrognati ( $p<0.00 \mathrm{I}, \mathrm{OR}: 9.38,95 \% \mathrm{Cl}$ : $2.7 \mathrm{I}-45.93)$ ve UAS ( $<<0.00 \mathrm{I}, \mathrm{OR}$ : 58.0I3, $95 \%$ Cl: 14.025-239.98) varlı̆ıı septoplasti geçirecek hastalarda zor havayolu açısından risk faktörü olarak bulundu.

Sonuç: Havayolu operasyon öncesi zor entübasyon açısından değerlendirilmeli ve minör cerrahi bile olsa zor havayolu için risk faktörleri belirlenmelidir.

Anahtar Sözcükler: Cormack-Lehane sınıflaması, Mallampati testi, mikrognati, septal deviasyon, uyku apne sendromu, zor havayolu. 